\title{
Statins in Peripheral Arterial Disease
}

Scott T. Chiesa PhD ${ }^{1}$, Nikos Papageorgiou MD, $\mathrm{PhD}^{1}$, Marietta Charakida MD, PhD 1,2

1. Institute of Cardiovascular Science, University College London, UK

2. Division of Imaging Sciences \& Biomedical Engineering, Kings College London, UK

Running Title: statins and peripheral arterial disease

Keywords: statins, outcomes, peripheral arterial disease, pleiotropic effects

Corresponding Author:

Marietta Charakida MD, PhD

Division of Imaging Sciences \& Biomedical Engineering

St Thomas' Hospital, Kings College London

London, UK, SE1 7EH

Tel: +44(0)20 71885444

Fax: +44 (0)20 71885442 


\section{ABSTRACT}

Peripheral arterial disease (PAD) is a common atherosclerotic condition affecting the lower extremities. PAD patients share similar cardiovascular risk factors to coronary artery disease patients and suffer from increased cardiovascular morbidity and mortality. Statins have been widely used in coronary artery disease patients but have been underused in patients with PAD. In the current review, we present data which support the beneficial role of statins in both reducing cardiovascular events and improving symptom-related outcomes in PAD patients. Alongside their lipid lowering effects, their pleiotropic actions are also discussed. Recent guidelines, which strongly recommend the administration of statins in PAD patients, are also presented. 


\section{ABBREVIATIONS}

ABI - ankle-brachial index

ACC/AHA - American College of Cardiology/ American Heart Association ADMA - asymmetric dimethylarginine

apoA1 - apolipoprotein A1

BH4 - tetrahydrobiopterin

CAD - coronary artery disease

CV-cardiovascular

CBVD - cerebrovascular disease

CLI - critical limb ischaemia

CRP - c-reactive protein

CVD - cardiovascular disease

eNOS - endothelial nitric oxide synthase

ESC - European Society of Cardiology

ET-1 - endothelin 1

FMD - flow mediated dilation

FPP - farnesylpyrophosphate

GGPP - geranylgeranylpyrophosphate

HDL-c - high density lipoprotein cholesterol

HMG-CoA -3-hydroxy-3-methylglutaryl-coenzyme A

IC - intermittent claudication

ICAM-1 - intercellular adhesion molecule 1

IL-6 - interleukin 6

IMT - intima media thickness

LDL-c - low-density lipoprotein cholesterol

MACE - major adverse cardiac events

MPO - myeloperoxidase

NADPH-oxidase - nicotinamide adenine dinucleotide phosphate oxidase

NO - nitric oxide

ox-LDL-c - oxidised low density lipoprotein cholesterol

PAD - peripheral arterial disease

PI3K-Akt - phosphatidylinositol-3 kinase/a serine threonine kinase

PON-1 - paraoxonase 1

RCT - randomised controlled trial

ROS - reactive oxygen species

SMC - smooth muscle cells

SOD - superoxide dismutase

TNF- $\alpha$ - tumour necrosis factor $\alpha$

VCAM-1 - vascular cellular adhesion molecule 1 


\section{INTRODUCTION}

Peripheral arterial disease (PAD) is a term most commonly used to describe an atherosclerotic condition in the lower extremities and is thought to be the third most common cause of cardiovascular (CV) morbidity and mortality. Epidemiological data has suggested that up to 202 million people globally may currently be living with PAD, with this figure increasing with age from $~ 6 \%$ at the age of 50 years up to $>20 \%$ at the age of 90 years (1).

Although most PAD patients are asymptomatic, the predominant complication encountered in those who do report symptoms is that of intermittent claudication (IC) - a painful cramping of the leg typically brought on by exercise and occurring as a result of inadequate blood flow to the working muscle bed due to blocked or narrowed arteries. As the severity of the disease progresses, IC may develop into more serious complications such as leg ulcers, critical limb ischaemia (CLI), and the potential need for limb amputation. Even when asymptomatic, the presence of PAD (as most commonly identified by an anklebrachial index $(\mathrm{ABI})<0.9)$ remains a strong risk marker for accompanying atherosclerotic disease, with up to $56 \%$ of individuals with PAD in major trials found to have accompanying CAD or cerebrovascular disease (CBVD) $(2,3)$. While these concomitant diseases are most likely driven by the same risk factors, there are limited data available about the impact of risk factor modification on morbidity and mortality in PAD patients (4).

A range of different pharmacological therapies have been used for the treatment of PAD in order to both relieve symptoms and to slow atherosclerotic disease progression. HMG-CoA reductase inhibitors, more commonly known as statins, are among the most prescribed drugs in the world and are a cornerstone of CV disease management and treatment. Although the primary mechanism of statins is the lowering of cholesterol production through the competitive inhibition of 3 hydroxy-3-methylglutaryl-coenzyme A reductase, it is now also clear that the inhibition of multiple other downstream pathways results in numerous pleiotropic effects which may act to further reduce atherosclerotic CV disease 
risk over and above the lowering of LDL-c (5). While a wealth of research has provided evidence for the ability of statins to reduce CV risk in patients with established CAD and CBVD, much less attention has focused on their effectiveness in PAD patients.

In this review, we will present data supporting the clinical benefit of statins both in relieving symptoms and improving $\mathrm{CV}$ outcomes in patients with $\mathrm{PAD}$, and will discuss mechanistic pathways relevant to the pathophysiology of PAD that can be affected by statin use.

\section{STATINS AND CARDIOVASCULAR EVENTS IN PVD (Table 1)}

The largest study to date on the efficacy of statin therapy in peripheral vascular disease is that of the Heart Protection Study (HPS), a multi-centre randomised clinical trial of over 20,000 patients in which 6748 patients were identified as having PAD. In this study, 40mg of simvastatin daily over a median of 5 years was found to significantly reduce the occurrence of major CV events in patients with PAD by approximately one-quarter. The magnitude of this effect was similar to that seen in the trial population as a whole, was unaffected by whether patients had any record of prior myocardial infarction or CAD, and was evident even in those presenting with low levels of LDL-c prior to treatment (6). Another prospective observational study in a cohort of 660 elderly patients with symptomatic PAD and serum LDL-c levels $>3.23 \mathrm{mmol} / \mathrm{L}$ confirmed these findings. With a mean follow-up of 39 months, those treated with statins had a relative risk ratio for new coronary events of 0.48 if they had suffered a previous myocardial infarction or 0.41 if they had not (7). Similar findings were also reported in a longer-term observational study looking at statin use in 2,420 patients with an ABI $<0.9$ who were followed for 8 years. This study showed a $54 \%$ reduction in mortality in patients treated with statins after adjustment for all baseline variables and propensity scores (8).

Expanding upon these findings, a number of studies have assessed the effect of more intense lipid-lowering therapy on both PAD incidence and long-term 
mortality outcomes. Stoekenbroek and colleagues investigated the effect of highdose atorvastatin therapy vs. usual-dose simvastatin therapy in 8888 randomlyallocated post-MI patients enrolled in the IDEAL trial, reporting a significantly lower hazard ratio for developing PAD $(H R=0.70)$ in the high-intensity group over a median 4.8 year follow-up. In addition, in those already suffering from $\mathrm{PAD}$, the authors noted a significant reduction in overall CV and coronary events in the high-intensity group alongside significantly fewer coronary revascularisations (9). A separate study, investigated the effect of intensified lipid-lowering therapy on long-term mortality outcomes in relation to LDL-c levels and reported that further lowering of LDL-c was associated with reduced all-cause mortality and higher statin doses were also associated with improved outcomes overall (10). These results have been supported by the data of a Cochrane meta-analysis on 17 lipid lowering trials, revealing a $26 \%$ reduction of $\mathrm{CV}$ events in patients treated with statins - mostly due to reduction in the incidence of coronary events (11). Although a number of lipid lowering drugs were assessed, the most consistent benefits on CV mortality and morbidity were shown with statins, particularly simvastatin when used in patients with high cholesterol levels (>3.5mmol/L).

\section{STATINS AND SYMPTOM-RELATED OUTCOMES IN PAD (Table 2)}

Irrespective of their effect on $\mathrm{CV}$ mortality, the use of statins in PAD patients has been associated with improvement in clinical symptoms - i.e. symptoms of IC, improvement in walking distance, and outcomes following vascular interventions/surgery. This was first evidenced in a sub-analysis of the aforementioned $4 \mathrm{~S}$ study, where a $38 \%$ reduction in the risk of new or worsening intermittent claudication and a $48 \%$ reduction in new or worsening carotid bruits was reported in patients assigned to simvastatin treatment and who were followed up for a median of 5.4 years (12).

A number of additional studies from the early 2000s further supported this positive effect of different statins on IC and walking distance. Mohler and colleagues randomised 354 patients with PAD and IC to receive either placebo, $10 \mathrm{mg}$ or $80 \mathrm{mg}$ atorvastatin daily for 12 months and noted a significant increase 
in community based physical activity (as assessed by questionnaire) in both groups as well as increased pain-free walking time in the $80 \mathrm{mg}$ statin group (63\% vs. 38\% increase) when compared to placebo at 12 months (13). Similar results were subsequently reported in patients taking 40mg simvastatin daily, with a $24 \%$ and $42 \%$ increase in exercise-induced time to onset of claudication at 6 and 12 months respectively (14). Likewise, in 86 hypercholesterolaemic patients randomised to $40 \mathrm{mg}$ simvastatin daily or placebo for 6 months, those in the statin group had improvements in pain-free walking distance, total walking distance, ankle-brachial index, and symptoms of claudication (15). These beneficial actions of statins in reducing morbidity in PAD patients are thought to occur due to mechanisms over and above their primary lipid-lowering actions. For instance, in a study where lower-extremity function was investigated in 392 patients both with and without PAD, individuals on statins had superior leg functioning compared to those who did not receive statin and this effect was independent of cholesterol levels. These findings suggest that other mechanisms such as decreased inflammation and improved endothelial function may account for the improvement in performance noted in PAD patients (16).

In patients with more advanced forms of lower-extremity PAD requiring surgical intervention or limb amputation, there is also good evidence for the ability of statins to reduce post-operative mortality risk (17-21). Results on local events such as restenosis, graft patency and limb salvage, however, come predominantly from retrospective reviews, and are therefore less clear. In those undergoing arterial reconstructions, statins have been shown to improve patency of autogenous infrainguinal bypass grafts in some $(22,23)$ but not all studies (19). Data involving the effects of statins on restenosis following surgical interventions is limited, although a retrospective review of 218 patients undergoing either endovascular interventions or bypass grafts has suggested a beneficial effect of statin use in these individuals (24) Beneficial findings have also been reported in a number of studies involving patients presenting with CLI, with those on statins found not only to have lower rates of overall mortality and major adverse cardiovascular events, but also to have improved limb salvage and amputation-free survival outcomes $(18,20,23,25)$. Similar to findings 
surrounding graft patency, however, these outcomes have not been consistently reproduced in all studies, and warrant further investigation $(17,19)$.

\section{ANTI-ATHEROSCLEROTIC EFFECTS OF STATINS IN PAD}

\section{- Pathophysiology of atherosclerosis (Figure 1)}

The prevailing theory of atherogenesis involves lipid retention and oxidation within the vessel wall in response to a compromised endothelium, and therefore the primary beneficial effect of statins is commonly attributed to their ability to lower LDL cholesterol levels, slowing atherosclerotic progression and leading to regression of established atheroma. Alongside lipid retention, however, multiple other inflammatory, oxidative, and proliferative pathways contribute to the complex atherosclerotic process. The accumulation of modified lipid particles within the sub-intimal space triggers an innate inflammatory response, further activating endothelial cells and stimulating the secretion of adhesion molecules (e.g. ICAM-1, VCAM-1), reactive oxygen species (e.g. superoxide) and numerous pro-inflammatory cytokines and chemokines (e.g. CRP, TNF- $\alpha$, IL-6) which act to draw monocytes and lymphocytes into the vessel wall. Upon entry, monocytes differentiate first into macrophages and then, after the uptake of oxidised lipids, into foam cells. Over time, smooth muscle cells (SMCs) proliferate in the lesion due to both migration from the tunica media and also division of existing muscle cells within the intima itself. The production of interstitial collagen and elastin by these cells results in the formation of a fibrous cap overlying a lipid-rich necrotic core, the latter of which is formed from the apoptosis of SMCs and lipid-laden macrophages and subsequent release of their contents. Once established, these atherosclerotic plaques are common causes of major CV events such as myocardial infarction or stroke, and may contribute to the symptoms experienced in PAD.

\section{- Statins and lipid profiles in PAD}


While the lipid profile of patients with PAD is commonly that of the metabolic syndrome, comprising of high triglyceride levels and low HDL cholesterol, alteration in these lipid fractions has been studied less than the effect of lowering the LDL cholesterol. Statins lower LDL primarily through the inhibition of the HMG-CoA-reductase enzyme, which catalyses the first step of cholesterol synthesis in the mevalonate pathway. This inhibition results in up-regulation of LDL receptor on the hepatocyte membrane, thereby increasing uptake of LDL particles from the plasma. While the ability of newer statins to lower LDL by up to $50 \%$ is well known (26), they have also been shown to decrease triglyceride levels to a lesser degree (up to 20\%), presumably through the inhibition of its synthesis in the liver and enhancement of lipoprotein lipase enzyme activity in the adipocytes (27).

Statins have also been shown to increase levels of high density lipoprotein (HDL) by up to $10 \%$, but the precise mechanism of this effect is unclear. HDL inhibits the progression of the atherosclerotic process by facilitating the reverse transport of cholesterol from lipid laden monocytes in the vascular wall and also by modulating the inflammatory response (28). The HDL-raising properties of statins may result from the induction of the apolipoprotein-A1 (apoA1) gene through the activation of peroxisome proliferator-activated receptors (29). However other pathways, affected by statins, might contribute to improvement not only in the levels but also in the function of HDL. HDL can become dysfunctional and pro-atherogenic in the presence of increased oxidative stress which is commonly seen in patients with PAD (30). Increased levels of myeloperoxidase (MPO), a key generator of oxidative stress, has been associated with increased CV risk in PAD patients(31) and statins can reduce oxidative stress by reducing both MPO activity (32) but also increases in PON-1 activity(33).

\section{- Statins and plaque stabilisation/regression in PAD}

Clinical studies have shown that the improvement in lipid profile observed following statin therapy is associated with a halt in the progression or even regression of atherosclerosis in PAD. Numerous studies have reported a slowing 
or regression of intimal-medial thickening (IMT) - a commonly used surrogate marker for atherosclerotic disease progression - in various vascular beds following statin treatment. In the carotid artery, multiple studies have reported beneficial changes in IMT in patients with established CV risk factors such as hypercholesterolemia (34-36) or hypertension (37). In the Kuopio Atherosclerosis Prevention Study (KAPS), this effect was found to occur even in individuals at low overall risk of atherosclerotic disease and was observed to be greater in smokers than non-smokers (36). Similar results have been reported in the superficial femoral artery, a site particularly prone to the development of lower-extremity PAD $(38,39)$, and have been shown to be visible in as early as 48 weeks following statin treatment, which suggests the contribution of non-lipidlowering mechanisms to the observed response (38). These changes appear to follow a dose-response pattern, with more aggressive therapy promoting IMT regression. For example, in type 2 diabetic patients - a population at increased risk of PAD - two years of cerivastatin or simvastatin treatment showed no effect on cIMT progression (40). In a later study assessing a similar population, however, although standard lipid lowering treatment had no effect on cIMT progression $(0.039 \mathrm{~mm}$ increase over 3 years), more aggressive lipid lowering (LDL lowered by $\sim 30 \mathrm{mg} / \mathrm{dl}$ ) therapy was found not only to slow progression, but to result in a significant regression of cIMT of $0.012 \mathrm{~mm}$ when used alone, or $0.025 \mathrm{~mm}$ when combined with ezetimibe (41).

Similar results have been reported for established atherosclerotic plaques. Statin treatment has been shown to reduce plaque volume and prevent acute, unstable coronary events through stabilisation of the "vulnerable plaque". Statins have the ability to improve the stability of these vulnerable plaques through the depletion of lipid levels; inhibition of LDL oxidation, inflammation, smooth muscle cell proliferation and apoptosis; and increase in collagen content within the plaque itself (42). In support of this, previous imaging studies have shown the slowing of PAD progression, when statin was administered over a 2 year period, in men $<$ 70 years old with established CAD, serum cholesterol levels of $155-310 \mathrm{mg} / \mathrm{dl}$, and triglycerides $<354 \mathrm{mg} / \mathrm{dl}$ (39). Similar results have also been observed following low dose atorvastatin treatment $(20 \mathrm{mg} /$ day), with reduction in 
femoral artery IMT being observed within as little as 4 weeks from initiation of treatment (38).

\section{- Pleiotropic effects of statins in PAD}

Although the primary mechanism of statins is the lowering of cholesterol production, it is now also clear that the inhibition of multiple other downstream pathways results in numerous pleiotropic effects which may act to further reduce atherosclerotic CVD risk over and above the lowering of LDL-c (5). This is especially pertinent in $\mathrm{PAD}$, given that the association between plaque size/stability and symptoms is less clear than that encountered in CAD. With evidence suggesting that the predominant PAD symptom of IC may be more closely linked to factors such as inflammation, endothelial dysfunction, skeletal muscle adaptations, and mitochondrial dysfunction rather than simply the presence of a flow-limiting lesion within the vessel lumen (15), the pleiotropic effects of statins in this population may offer benefits over and above that caused by lipid lowering alone.

\section{Statins and endothelial function in PAD}

Endothelial dysfunction underlies every stage of atherosclerotic disease and numerous studies have demonstrated disturbed endothelial physiology in patients suffering from peripheral vascular disease, measured both invasively via vasodilator infusion $(43,44)$ and non-invasively via flow-mediated dilation (FMD) of the brachial artery (45). Furthermore, inverse relationships between PAD severity and endothelial function have been observed when comparing PAD patients with age- and sex-matched controls, with FMD in symptomatic PAD being less than half that of healthy equivalents (5.1\% vs. 11.7\%) (45). Similar findings have been reported in a study of 199 patients presenting for elective vascular surgery and subsequently followed for 1.2 years, with significantly lower FMD reported in patients who experienced a major cardiovascular event than those who did not (4.4\% vs. $7 \%$ ) (46). Although the mechanisms by which statins can affect the endothelium in the setting of PAD have not been explored, 
it is reasonable to believe that statins can affect similar pathways to those reported in CAD patients or in individuals who share the same risk factors as PAD patients.

The effect of statins on endothelial function was initially thought to be simply related to its lipid lowering actions (47). For instance, a study in patients with known CAD has previously reported a sustained improvement in FMD over 10 months which occurred in combination with a lowering of LDL-c levels by $\sim 25 \%$ following statin therapy(48). Similar improvements have also been observed in hypercholesterolaemic men following eight weeks of simvastatin treatment (49), while cessation of the same statin for 6 weeks had the opposite effect (50). Furthermore, a single session of LDL apheresis has previously been shown to acutely improve endothelial function (51), and in vitro studies have demonstrated the ability of oxidised LDL to reduce endothelial nitric oxide (NO) release (52). However, numerous studies have demonstrated that statins may exert additional beneficial endothelial effects through alternative pathways (53). Seminal work by Laufs and colleagues supported this hypothesis by showing the ability of statins to exert direct effects on endothelial NO synthesis and bioavailability through the upregulation of endothelial nitric oxide synthase (eNOS)(54). These effects are likely to be mediated through the ability of statins to block the synthesis of isoprenoid intermediates such as farnesylpyrophosphate (FPP) and geranylgeranylpyrophosphate (GGPP), molecules which lie on the same metabolic pathway as that responsible for cholesterol synthesis and are therefore simultaneously affected by HMG-CoA reductase inhibition (55). Furthermore, activation of a separate phosphatidylinositol-3 kinase/Akt (PI3K-Akt) mediated pathway has also been reported following statin treatment (56), providing yet another alternative pathway for eNOS activation. Statins can also increase NO synthesis by lowering plasma levels of asymmetric dimethylarginine (ADMA)-an endogenous inhibitor of nitric oxide synthesis- which is upregulated in PAD patients and has been shown to predict risk of major adverse cardiovascular events (MACE)(57)(58). 
In addition to their beneficial effects on NO bioavailability, statins have also been shown to affect circulating levels of numerous other vasoactive peptides produced by the endothelium. Endothelin-1 (ET-1) is a potent vasoconstrictor implicated in the pathophysiology of $\operatorname{PAD}(59,60)$ and has been shown in a recent meta-analysis of 15 RCTs to be significantly lowered following statin use (weighted mean difference of $-0.30 \mathrm{pg} / \mathrm{ml}$ ) when compared to placebo (61). This decrease is thought to be related to the down-regulation of prepro-endothelin-1 mRNA via Rho protein-associated pathways $(62,63)$, and is maintained even in the presence of ox-LDL (62). In addition to reducing ET-1 synthesis, statins may also exert additional beneficial effects through the attenuation of vascular smooth muscle responsiveness to ET-1 vasoconstriction, as shown by the ability of simvastatin to exert a concentration-dependent relaxation of isolated aortic rings pre-contracted with ET-1 (64).

\section{Anti-inflammatory effects of statins in PAD}

Increased inflammatory markers are associated with both intermittent claudication and increased CV mortality in patients with PAD. A nested casecontrol study carried out in 1998 as part of the Physicians Health Study was one of the first major studies to specifically investigate the association between $\mathrm{C}$ reactive protein (CRP) and future risk of developing symptomatic PAD (65), and found that median CRP levels were not only significantly higher in participants who developed PAD, but that the relative risk of future complications increased in line with baseline CRP concentration. These findings were replicated in a cohort of 475 women in the RATIO study (66), and in the Edinburgh Artery Study, in which CRP was found to be related to PAD severity in a cohort of over 1500 individuals (67). After 12 years of follow-up in the latter study; the inflammatory markers CRP, interleukin- 6 and intercellular adhesion molecule -1 were all shown to be associated with the progression of atherosclerotic disease, even after adjustment for other CV risk factors. Although these effects may occur due to a lowering of inflammatory ox-LDL within the vascular wall, a wealth of evidence also exists to suggest additional anti-inflammatory effects of statins that occur over and above their LDL-lowering properties and that these are 
mediated through mechanistic pathways lying downstream of HMG-CoA inhibition. The PRavastatin Inflammation/CRP Evaluation (PRINCE) trial, conducted in 2001, was the first major trial to investigate whether the pleiotropic properties of statins could reduce inflammation independent of their cholesterol-lowering properties in a normolipidaemic population (68). In this randomised, placebo-controlled, double-blind clinical trial, 1702 individuals with no prior history of CVD were assigned to receive $40 \mathrm{mg} / \mathrm{d}$ pravastatin or placebo for 24 weeks, with the changes in CRP and cholesterol assessed at both baseline and end of study. At the half-way point of the study, a decrease in CRP levels was already evident in the statin group (14.7\% reduction), and this was maintained until the end of the study (16.9\% reduction). These changes were independent of the statins effect on LDL-c, and were subsequently replicated in a second openlabel trial carried out by the same investigators (68). Similarly, in the JUPITER trial, $20 \mathrm{mg} /$ daily rosuvastatin for 1.9 years was shown to reduce CRP by $37 \%$ in patients who presented with normolipidaemia $(<130 \mathrm{mg} / \mathrm{dl})$ but elevated CRP levels (> $2.0 \mathrm{mg} / \mathrm{l}$ ) (69). Likewise, in a secondary prevention trial involving PAD patients, patients receiving statin therapy had significantly lower levels of numerous inflammatory markers when compared to controls (70).

\section{Statins and oxidative stress in PAD}

Patients with established PAD exhibit higher levels of oxidative stress when compared to healthy controls (71), with this increase occurring due to a combination of both increased reactive oxygen (ROS) production and decreased antioxidant enzyme activity. ROS can be produced at multiple sites within the vascular wall via pathways such as $\mathrm{NAD}(\mathrm{P}) \mathrm{H}$ oxidase, xanthine oxidase, myeloperoxidase, eNOS uncoupling, a dysfunctional electron transport chain, and the activation of macrophages and T-cells (72,73). Under normal physiological conditions, the production of these free radicals is balanced by endogenous antioxidant activity such as superoxidase dismutase (SOD) and glutathione reductase, preventing their accumulation and subsequent generation

of oxidative stress. This balance is disrupted in PAD leading to an excess of reactive oxygen species and chronic oxidative stress. 
Statins have been shown to reduce oxidative stress by decreasing the expression and activation of key enzymes such as NADH/NADPH oxidase and xanthine oxidase. Atorvastatin therapy in normocholesterolaemic hypertensive rats resulted in improved endothelial function in line with a decrease in ROS (62\% of control), a decrease in expression of the NAD(P)H oxidase subunit p22phox (63\% of control), and an upregulation of eNOS mRNA expression and activity (74). In human studies, the assessment of gp91phox mRNA expression (a substrate-binding unit of endothelial NADPH oxidase) in internal mammary artery biopsies of patients both on and off statins has indicated the presence of a decreased level of vascular NAD(P)H-oxidase expression and superoxide formation only in the arteries extracted from statin patients (75). Although lipidlowering per se can contribute to a reduction in oxidative stress (76), statins also appear to be able to further reduce ROS production through a separate NADPHoxidase inhibitory pathway. Long-term rosuvastatin treatment in mice has been shown to decrease superoxide production through an NADPH-oxidase pathway (77), while atorvastatin treatment in hypercholesterolaemic patients displays a dose-dependent reduction in isoprostanes from as early as 3 days administration (78). Statins have also been shown to reduce superoxide formation from human monocyte-derived macrophages (79).

In vitro work has demonstrated the ability of cerivastatin to not only upregulate eNOS expression, but also to increase tetrahydrobiopterin (BH4) synthesis in endothelial cells through an upregulation of GTP-cyclohydrolase I gene expression (80). Similarly, in clinical studies, in patients undergoing coronary artery bypass surgery, pre-treatment with atorvastatin 3 days prior to surgery resulted in an increase in vascular BH4 and a corresponding decrease in superoxide production prior to any changes in lipid levels (81). As well as reducing oxidative stress through inhibition of ROS generating pathways, statins have also been shown to exert further reductions in oxidative stress by promoting antioxidant pathways, as evidenced by the ability of simvastatin to up-regulate superoxide dismutase activity in hypertensive rats (82). 


\section{GUIDELINES FOR THE USE OF STATINS IN PAD}

A number of studies have provided strong evidence about the beneficial role of statins in patients with PAD. The European Society of Cardiology (ESC) guidelines for the diagnosis and treatment of PAD recommend a target LDL-C below $100 \mathrm{mg} / \mathrm{dl}$ and optimally below $70 \mathrm{mg} / \mathrm{dl}$ (Class I recommendation) in all patients with PAD regardless of baseline LDL-C levels. When the target level cannot be reached, a reduction of $>50 \%$ in LDL-C should be attempted (83). These recommendations are similar to those of the American College of Cardiology/ American Heart Association (ACC/AHA), who suggest a target for LDL-C level $<100 \mathrm{mg} / \mathrm{dl}$ (Class I recommendation) in all patients with PAD and LDL level $<70 \mathrm{mg} / \mathrm{dl}$ for patients at very high risk of ischaemic events (Class IIa recommendation). For patients with PAD and high triglycerides/low HDL but normal LDL, ACC has an additional Class IIa recommendation for the use of fibric acid derivatives (84). According to 2013 ACC/AHA guidelines moderate or high dose statin therapy is advocated in all symptomatic PAD patients to reduce the risk of $\mathrm{CV}$ events (85). For the management of PAD patients who are undergoing non-cardiac vascular surgery, the 2014 ACC/AHA guidelines also recommend the initiation of statin therapy, irrespective of their underlying risk factor profile, for reduction in the incidence of CV events (Class IIa recommendation) (86).

Although a threshold for LDL-C is recommended by the guidelines, there are still questions as to how intensive statin therapy should be, as side effects such as myopathy, liver damage, and an increased risk of type 2 diabetes are all wellrecognised risks with this medication. In support of intensive statin therapy in PAD, higher statin doses have been shown not only to reduce CV events in patients with pre-existing PAD (10), but also to reduce the incidence of PAD in primary prevention (9). Two large scale meta-analyses have attempted to clarify the threshold at which the possible benefits of statins are outweighed by their adverse effects. Although high-dose statin therapy was found to provide substantial clinical benefit when compared to low-dose therapy and placebo, both studies reported an accompanying increase in the risk of adverse events in the intensively treated group $(87,88)$. These events, however, were found to 
consist predominantly of non-urgent conditions such as myalgia or liver enzyme elevations, with serious events remaining rare and not differing significantly between the high-dose and placebo groups (88).This increase in risk appeared to be significantly outweighed by its clinical benefits, however, with data suggesting a reduction in CV events of 37 per 1000 patients, as opposed to the appearance of only 5 adverse events in the same number of subjects. Similar findings have also been reported from the JUPITER trial, in which a reduction in all-cause mortality was observed in $20 \%$ of patients receiving rosuvastatin and in $46 \%$ of patients that attained target levels of $\mathrm{LDL}-\mathrm{C}<50 \mathrm{mg} / \mathrm{dl}$ over a median period of 2 years (89). Notably in this trial, the rate of adverse effects was again similar in the placebo and statin groups (except for muscle symptoms). These findings strongly suggest that the benefits of intensive statin treatment outweigh the possible adverse effects, particularly in high-risk patients.

While there is limited evidence regarding the monitoring of lipid lowering treatment, the ESC recommends a first assessment of the response to therapy at $8+/-4$ weeks following initiation of statin treatment and thereafter annual follow up monitoring once the patient has reached the lipid lowering targets (83). Furthermore, while there is no clear evidence of a high risk of adverse effects of low LDL-C levels, the ACC guidelines recommend decreasing statin dosage if two consecutive values of LDL-C are below $40 \mathrm{mg} / \mathrm{dl}$ (84).

As previously mentioned, moderate doses of statin therapy have been associated with myopathy, liver disease, increased incidence of diabetes development and cognitive impairment. In randomized clinical trials, however, myalgia - the most common adverse effect following statin use - has shown similar presentation in both statin and placebo groups (90). The European Atherosclerosis Society consensus panel recommends that, in the presence of muscle pain or weakness, creatine kinase levels should be obtained and, in case that the levels are elevated, statins should be discontinued and subsequently restarted at a lower dose. The American Academy of Family Physicians on the other hand offers a Class C recommendation and only in patients at high risk of muscle toxicity baseline creatine kinase levels should be obtained (91). Overall, the side effects reported 
with statin use in PAD patients are rare and, for most patients, the risk-to-benefit calculation involving these adverse effects favours statin use.

\section{CONCLUSIONS}

Peripheral vascular disease is under-diagnosed and is a major risk factor for CVD morbidity and mortality. Despite the high prevalence of atherosclerotic risk factors in those suffering from the disease, PAD patients receive less intensive treatment than those diagnosed with CAD (2) and have a long-term prognosis that is significantly worse (92). A wealth of evidence exists for the ability of statins to exert beneficial effects on numerous pathophysiological pathways that underlie every stage of the disease, and clinical evidence from large-scale observational studies and randomised control trials provide strong evidence for their ability to significantly diminish morbidity and mortality. Better screening for PAD and improved pharmacological interventions with drugs such as statins are likely to improve outcomes and help to reduce the significant health and financial burdens associated with this prevalent disease. 


\section{REFERENCES}

1. Fowkes FGR, Rudan D, Rudan I, Aboyans V, Denenberg JO, McDermott MM, et al. Comparison of global estimates of prevalence and risk factors for peripheral artery disease in 2000 and 2010: a systematic review and analysis. Lancet. 2013;382(9901):1329-40.

2. Hirsch AT, Criqui MH, Treat-Jacobson D, Regensteiner JG, Creager MA, Olin JW, et al. Peripheral Arterial Disease Detection, Awareness, and Treatment in Primary Care. JAMA. 2001;286(11):1317.

3. Leng GC, Lee AJ, Fowkers FGR, Whiteman M, Dunbar J, Housley E, et al. Incidence, Natural History and Cardiovascular Events in Symptomatic and Asymptomatic Peripheral Arterial Disease in the General Population. Int J Epidemiol. 1996;25(6):1172-81.

4. Diehm C, Allenberg JR, Pittrow D, Mahn M, Tepohl G, Haberl RL, et al. Mortality and Vascular Morbidity in Older Adults With Asymptomatic Versus Symptomatic Peripheral Artery Disease. Circulation. 2009;120(21).

5. Mihos CG, Pineda AM, Santana O. Cardiovascular effects of statins, beyond lipid-lowering properties. Pharmacol Res. 2014;88:12-9.

6. Heart Protection Study Collaborative Group D, Blackburn H, Higgins M, Stamler J, Vaccaro 0, Neaton J, et al. MRC/BHF Heart Protection Study of cholesterol lowering with simvastatin in 20,536 high-risk individuals: a randomised placebo-controlled trial. Lancet. 2002;360(9326):7-22.

7. Aronow WS, Ahn C. Frequency of new coronary events in older persons with peripheral arterial disease and serum low-density lipoprotein cholesterol $\geq 125 \mathrm{mg} / \mathrm{dl}$ treated with statins versus no lipid-lowering drug. Am J Cardiol. 2002;90(7):789-91.

8. Feringa HHH, van Waning VH, Bax JJ, Elhendy A, Boersma E, Schouten O, et al. Cardioprotective Medication Is Associated With Improved Survival in Patients With Peripheral Arterial Disease. J Am Coll Cardiol. 2006;47(6):1182-7.

9. Stoekenbroek RM, Boekholdt SM, Fayyad R, Laskey R, Tikkanen MJ, Pedersen TR, et al. High-dose atorvastatin is superior to moderate-dose simvastatin in preventing peripheral arterial disease. Heart. 
2015;101(5):356-62.

10. Feringa HHH, Karagiannis SE, van Waning VH, Boersma E, Schouten O, Bax JJ, et al. The effect of intensified lipid-lowering therapy on long-term prognosis in patients with peripheral arterial disease. J Vasc Surg. 2007;45(5):936-43.

11. Aung PP, Maxwell H, Jepson RG, Price J, Leng GC. Lipid-lowering for peripheral arterial disease of the lower limb. In: Aung PP, editor. Cochrane Database of Systematic Reviews. Chichester, UK: John Wiley \& Sons, Ltd; 2007. p. CD000123.

12. Pedersen TR, Kjekshus J, Pyörälä K, Olsson AG, Cook TJ, Musliner TA, et al. Effect of Simvastatin on Ischemic Signs and Symptoms in the Scandinavian Simvastatin Survival Study (4S). Am J Cardiol. 1998;81(3):333-5.

13. Mohler ER, Hiatt WR, Creager MA. Cholesterol reduction with atorvastatin improves walking distance in patients with peripheral arterial disease. Circulation. American Heart Association Journals; 2003;108(12):1481-6.

14. Aronow WS, Nayak D, Woodworth S, Ahn C. Effect of simvastatin versus placebo on treadmill exercise time until the onset of intermittent claudication in older patients with peripheral arterial disease at six months and at one year after treatment. Am J Cardiol. 2003;92(6):711-2.

15. Mondillo S, Ballo P, Barbati R, Guerrini F, Ammaturo T, Agricola E, et al. Effects of simvastatin on walking performance and symptoms of intermittent claudication in hypercholesterolemic patients with peripheral vascular disease. Am J Med. 2003;114(5):359-64.

16. Mcdermott MM, Guralnik JM, Greenland P, Pearce WH, Criqui MH, Liu K, et al. Statin Use and Leg Functioning in Patients With and Without LowerExtremity Peripheral Arterial Disease. Circulation. 2003;107:757-61.

17. Suckow BD, Kraiss LW, Schanzer A, Stone DH, Kalish J, DeMartino RR, et al. Statin therapy after infrainguinal bypass surgery for critical limb ischemia is associated with improved 5-year survival. J Vasc Surg. 2015;61(1):12633.

18. Kumbhani DJ, Steg PG, Cannon CP, Eagle KA, Smith SC, Goto S, et al. Statin therapy and long-term adverse limb outcomes in patients with peripheral artery disease: insights from the REACH registry. Eur Heart J. Oxford 
University Press; 2014 Nov 1;35(41):2864-72.

19. Schanzer A, Hevelone N, Owens CD, Beckman JA, Belkin M, Conte MS. Statins are independently associated with reduced mortality in patients undergoing infrainguinal bypass graft surgery for critical limb ischemia. J Vasc Surg. 2008;47(4):774-81.

20. Westin GG, Armstrong EJ, Bang H, Yeo K-K, Anderson D, Dawson DL, et al. Association Between Statin Medications and Mortality, Major Adverse Cardiovascular Event, and Amputation-Free Survival in Patients With Critical Limb Ischemia. J Am Coll Cardiol. 2014;63(7):682-90.

21. Ward RP, Leeper NJ, Kirkpatrick JN, Lang RM, Sorrentino MJ, Williams KA. The effect of preoperative statin therapy on cardiovascular outcomes in patients undergoing infrainguinal vascular surgery. Int J Cardiol. 2005;104(3):264-8.

22. Abbruzzese TA, Havens J, Belkin M, Donaldson MC, Whittemore AD, Liao $\mathrm{JK}$, et al. Statin therapy is associated with improved patency of autogenous infrainguinal bypass grafts. J Vasc Surg. 2004;39(6):1178-85.

23. Aiello FA, Khan AA, Meltzer AJ, Gallagher KA, McKinsey JF, Schneider DB. Statin therapy is associated with superior clinical outcomes after endovascular treatment of critical limb ischemia. J Vasc Surg. 2012;55(2):371-80.

24. Siracuse JJ, Giles KA, Pomposelli FB, Hamdan AD, Wyers MC, Chaikof EL, et al. Results for primary bypass versus primary angioplasty/stent for intermittent claudication due to superficial femoral artery occlusive disease. J Vasc Surg. 2012;55(4):1001-7.

25. Henke PK, Blackburn S, Proctor MC, Stevens J, Mukherjee D, Rajagopalin S, et al. Patients undergoing infrainguinal bypass to treat atherosclerotic vascular disease are underprescribed cardioprotective medications: effect on graft patency, limb salvage, and mortality. J Vasc Surg. 2004;39(2):35765.

26. Cholesterol Treatment Trialists' (CTT) Collaborators CTT (CTT), Mihaylova B, Emberson J, Blackwell L, Keech A, Simes J, et al. The effects of lowering LDL cholesterol with statin therapy in people at low risk of vascular disease: meta-analysis of individual data from 27 randomised 
trials. Lancet. 2012;380(9841):581-90.

27. Saiki A, Murano T, Watanabe F, Oyama T, Miyashita Y, Shirai K. Pitavastatin Enhanced Lipoprotein Lipase Expression in 3T3-L1 Preadipocytes. J Atheroscler Thromb. Japan Atherosclerosis Society; 2005;12(3):163-8.

28. Fuster V, Moreno PR, Fayad ZA, Corti R, Badimon JJ. Atherothrombosis and High-Risk Plaque: Part I: Evolving Concepts. J Am Coll Cardiol. 2005;46(6):937-54.

29. Yano M, Matsumura T, Senokuchi T, Ishii N, Murata Y, Taketa K, et al. Statins Activate Peroxisome Proliferator-Activated Receptor $\gamma$ Through Extracellular Signal-Regulated Kinase 1/2 and p38 Mitogen-Activated Protein Kinase-Dependent Cyclooxygenase-2 Expression in Macrophages. Circ Res. 2007;100(10).

30. Ali Z, Sarcia P, Mosley TH, Kondragunta V, Kullo IJ. Association of serum myeloperoxidase with the ankle-brachial index and peripheral arterial disease. Vasc Med. 2009;14(3):215-20.

31. Brevetti G, Schiano V, Laurenzano E, Giugliano G, Petretta M, Scopacasa F, et al. Myeloperoxidase, but not C-reactive protein, predicts cardiovascular risk in peripheral arterial disease. Eur Heart J. 2007;29(2):224-30.

32. Kumar AP, Reynolds WF. Statins downregulate myeloperoxidase gene expression in macrophages. Biochem Biophys Res Commun. 2005;331(2):442-51.

33. Ferretti G, Bacchetti T, Sahebkar A. Effect of statin therapy on paraoxonase-1 status: A systematic review and meta-analysis of 25 clinical trials. Prog Lipid Res. 2015;60:50-73.

34. Ozaki K, Kubo T, Imaki R, Shinagawa H, Fukaya H, Ohtaki K, et al. The antiatherosclerotic effects of lipid lowering with atorvastatin in patients with hypercholesterolemia. J Atheroscler Thromb. 2006;13(4):216-9.

35. Sawayama Y, Shimizu C, Maeda N, Tatsukawa M, Kinukawa N, Koyanagi S, et al. Effects of probucol and pravastatin on common carotid atherosclerosis in patients with asymptomatic hypercholesterolemia. Fukuoka Atherosclerosis Trial (FAST). J Am Coll Cardiol. 2002;39(4):6106.

36. Salonen R, Nyyssönen K, Porkkala E, Rummukainen J, Belder R, Park JS, et 
al. Kuopio Atherosclerosis Prevention Study (KAPS). A population-based primary preventive trial of the effect of LDL lowering on atherosclerotic progression in carotid and femoral arteries. Circulation. 1995;92(7):175864.

37. Anderssen SA, Hjelstuen AK, Hjermann I, Bjerkan K, Holme I. Fluvastatin and lifestyle modification for reduction of carotid intima-media thickness and left ventricular mass progression in drug-treated hypertensives. Atherosclerosis. 2005;178(2):387-97.

38. Youssef F, Seifalian AM, Jagroop IA, Myint F, Baker D, Mikhailidis DP, et al. The Early Effect of Lipid-lowering Treatment on Carotid and Femoral Intima Media Thickness (IMT). Eur J Vasc Endovasc Surg. W.B. Saunders; 2002;23(4):358-64.

39. de Groot E, Jukema JW, Montauban van Swijndregt AD, Zwinderman AH, Ackerstaff RGA, van der Steen AFW, et al. B-Mode Ultrasound Assessment of Pravastatin Treatment Effect on Carotid and Femoral Artery Walls and Its Correlations With Coronary Arteriographic Findings: A Report of the Regression Growth Evaluation Statin Study (REGRESS). J Am Coll Cardiol. 1998;31(7):1561-7.

40. Beishuizen ED, van de Ree MA, Jukema JW, Tamsma JT, van der Vijver JCM, Meinders AE, et al. Two-Year Statin Therapy Does Not Alter the Progression of Intima-Media Thickness in Patients With Type 2 Diabetes Without Manifest Cardiovascular Disease. Diabetes Care. 2004;27(12):2887-92.

41. Fleg JL, Mete M, Howard B V., Umans JG, Roman MJ, Ratner RE, et al. Effect of Statins Alone Versus Statins Plus Ezetimibe on Carotid Atherosclerosis in Type 2 Diabetes. J Am Coll Cardiol. 2008;52(25):2198-205.

42. Crisby M, Nordin-Fredriksson G, Shah PK, Yano J, Zhu J, Nilsson J. Pravastatin Treatment Increases Collagen Content and Decreases Lipid Content, Inflammation, Metalloproteinases, and Cell Death in Human Carotid Plaques. Circulation. 2001;103(7):926-33.

43. Fronek A, DiTomasso DG, Allison M. Noninvasive assessment of endothelial activity in patients with peripheral arterial disease and cardiovascular risk factors. Endothelium. 14(4-5):199-205. 
44. Weiss T, Fischer D, Hausmann D, Weiss C. Endothelial function in patients with peripheral vascular disease: influence of prostaglandin E1. Prostaglandins Leukot Essent Fat Acids. 2002;67:277-81.

45. Silvestro A, Scopacasa F, Ruocco A, Oliva G, Schiano V, Zincarelli C, et al. Inflammatory status and endothelial function in asymptomatic and symptomatic peripheral arterial disease. Vasc Med. 2003;8(4):225-32.

46. Gokce N, Keaney JF, Hunter LM, Watkins MT, Nedeljkovic ZS, Menzoian JO, et al. Predictive value of noninvasivelydetermined endothelial dysfunction for long-term cardiovascular events inpatients with peripheral vascular disease. J Am Coll Cardiol. 2003;41(10):1769-75.

47. Balk EM, Karas RH, Jordan HS, Kupelnick B, Chew P, Lau J. Effects of statins on vascular structure and function: A systematic review. Am J Med. 2004;117(10):775-90.

48. Frick M, Alber HF, Hügel H, Schwarzacher SP, Pachinger O, Weidinger F. Short- and long-term changes of flow-mediated vasodilation in patients under statin therapy. Clin Cardiol. 2002;25(6):291-4.

49. Neunteufl T, Kostner K, Katzenschlager R, Zehetgruber M, Maurer G, Weidinger F. Additional benefit of vitamin E supplementation to simvastatin therapy on vasoreactivity of the brachial artery of hypercholesterolemic men. J Am Coll Cardiol. 1998;32(3):711-6.

50. Stroes ESG, Koomans HA, Rabelink TJ, de Bruin TWA. Vascular function in the forearm of hypercholesterolaemic patients off and on lipid-lowering medication. Lancet. 1995;346(8973):467-71.

51. Tamai O, Matsuoka H, Itabe H, Wada Y, Kohno K, Imaizumi T. Single LDL apheresis improves endothelium-dependent vasodilatation in hypercholesterolemic humans. Circulation. 1997;95(1):76-82.

52. Liao JK, Shin WS, Lee WY, Clark SL. Oxidized low-density lipoprotein decreases the expression of endothelial nitric oxide synthase. J Biol Chem. 1995;270(1):319-24.

53. O'Driscoll G, Green D, Taylor RR. Simvastatin, an HMG-coenzyme A reductase inhibitor, improves endothelial function within 1 month. Circulation. 1997;95(5):1126-31.

54. Laufs U, La Fata V, Plutzky J, Liao JK. Upregulation of endothelial nitric 
oxide synthase by HMG CoA reductase inhibitors. Circulation. 1998;97(12):1129-35.

55. Rikitake Y, Liao JK. Rho GTPases, statins, and nitric oxide. Circ Res. 2005;97(12):1232-5.

56. Harris MB, Blackstone MA, Sood SG, Li C, Goolsby JM, Venema VJ, et al. Acute activation and phosphorylation of endothelial nitric oxide synthase by HMG-CoA reductase inhibitors. Am J Physiol Heart Circ Physiol. 2004;287(2):H560-6.

57. Böger RH, Sydow K, Borlak J, Thum T, Lenzen H, Schubert B, et al. LDL cholesterol upregulates synthesis of asymmetrical dimethylarginine in human endothelial cells: involvement of S-adenosylmethionine-dependent methyltransferases. Circ Res. 2000;87(2):99-105.

58. Mittermayer F, Krzyzanowska K, Exner M, Mlekusch W, Amighi J, Sabeti S, et al. Asymmetric Dimethylarginine Predicts Major Adverse Cardiovascular Events in Patients With Advanced Peripheral Artery Disease. Arterioscler Thromb Vasc Biol. 2006;26(11):2536-40.

59. Mangiafico RA, Malatino LS, Santonocito M, Sarnataro F, Dell'Arte S, Messina R, et al. Plasma endothelin-1 levels in patients with peripheral arterial occlusive disease at different Fontaine's stages. Panminerva Med. 1999;41(1):22-6.

60. de Haro Miralles J, Gónzalez AF, Varela Casariego C, García FA. Onset of peripheral arterial disease: role of endothelin in endothelial dysfunction. Interact Cardiovasc Thorac Surg. 2010;10(5):760-5.

61. Sahebkar A, Kotani K, Serban C, Ursoniu S, Mikhailidis DP, Jones SR, et al. Statin therapy reduces plasma endothelin-1 concentrations: A metaanalysis of 15 randomized controlled trials. Atherosclerosis. 2015;241(2):433-42.

62. Hernández-Perera O, Pérez-Sala D, Navarro-Antolín J, Sánchez-Pascuala R, Hernández G, Díaz C, et al. Effects of the 3-hydroxy-3-methylglutaryl-CoA reductase inhibitors, atorvastatin and simvastatin, on the expression of endothelin-1 and endothelial nitric oxide synthase in vascular endothelial cells. J Clin Invest. 1998;101(12):2711-9.

63. Hernández-Perera O, Pérez-Sala D, Soria E, Lamas S. Involvement of Rho 
GTPases in the transcriptional inhibition of preproendothelin-1 gene expression by simvastatin in vascular endothelial cells. Circ Res. 2000;87(7):616-22.

64. Mraiche F, Cena J, Das D, Vollrath B. Effects of statins on vascular function of endothelin-1. Br J Pharmacol. 2005;144(5):715-26.

65. Ridker PM, Cushman M, Stampfer MJ, Tracy RP, Hennekens CH. Plasma concentration of C-reactive protein and risk of developing peripheral vascular disease. Circulation. 1998;97(5):425-8.

66. Bloemenkamp DGM, van den Bosch MAAJ, Mali WPTM, Tanis BC, Rosendaal FR, Kemmeren JM, et al. Novel risk factors for peripheral arterial disease in young women. Am J Med. 2002;113(6):462-7.

67. Tzoulaki I, Murray GD, Lee AJ, Rumley A, Lowe GDO, Fowkes FGR. Creactive protein, interleukin-6, and soluble adhesion molecules as predictors of progressive peripheral atherosclerosis in the general population: Edinburgh Artery Study. Circulation. 2005;112(7):976-83.

68. Albert MA, Danielson E, Rifai N, Ridker PM, PRINCE Investigators. Effect of statin therapy on C-reactive protein levels: the pravastatin inflammation/CRP evaluation (PRINCE): a randomized trial and cohort study. JAMA. 2001;286(1):64-70.

69. Ridker PM, Danielson E, Fonseca FAH, Genest J, Gotto AM, Kastelein JJP, et al. Rosuvastatin to Prevent Vascular Events in Men and Women with Elevated C-Reactive Protein. N Engl J Med. 2008;359(21):2195-207.

70. Schillinger M, Exner M, Mlekusch W, Amighi J, Sabeti S, Muellner M, et al. Statin therapy improves cardiovascular outcome of patients with peripheral artery disease. Eur Heart J. 2004;25(9):742-8.

71. Belch JJ, Mackay IR, Hill A, Jennings P, McCollum P. Oxidative stress is present in atherosclerotic peripheral arterial disease and further increased by diabetes mellitus. Int Angiol. 1995;14(4):385-8.

72. Higashi Y, Noma K, Yoshizumi M, Kihara Y. Endothelial function and oxidative stress in cardiovascular diseases. Circ J. 2009;73(3):411-8.

73. Cathcart MK. Regulation of superoxide anion production by NADPH oxidase in monocytes/macrophages: contributions to atherosclerosis. Arterioscler Thromb Vasc Biol. 2004;24(1):23-8. 
74. Wassmann S, Laufs U, Bäumer AT, Müller K, Ahlbory K, Linz W, et al. HMGCoA reductase inhibitors improve endothelial dysfunction in normocholesterolemic hypertension via reduced production of reactive oxygen species. Hypertension. 2001;37(6):1450-7.

75. Rueckschloss U, Galle J, Holtz J, Zerkowski H-R, Morawietz H. Induction of NAD(P)H Oxidase by Oxidized Low-Density Lipoprotein in Human Endothelial Cells. Circulation. 2001;104(15).

76. Aikawa M, Sugiyama S, Hill CC, Voglic SJ, Rabkin E, Fukumoto Y, et al. Lipid Lowering Reduces Oxidative Stress and Endothelial Cell Activation in Rabbit Atheroma. Circulation. 2002;106(11):1390-6.

77. Otto A, Fontaine J, Tschirhart E, Fontaine D, Berkenboom G. Rosuvastatin treatment protects against nitrate-induced oxidative stress in eNOS knockout mice: implication of the NAD(P)H oxidase pathway. Br J Pharmacol. 2006;148(4):544-52.

78. Cangemi R, Loffredo L, Carnevale R, Perri L, Patrizi MP, Sanguigni V, et al. Early decrease of oxidative stress by atorvastatin in hypercholesterolaemic patients: effect on circulating vitamin E. Eur Heart J. 2008;29(1):54-62.

79. Giroux LM, Davignon J, Naruszewicz M. Simvastatin inhibits the oxidation of low-density lipoproteins by activated human monocyte-derived macrophages. Biochim Biophys Acta. 1993;1165(3):335-8.

80. Hattori Y, Nakanishi N, Akimoto K, Yoshida M, Kasai K. HMG-CoA Reductase Inhibitor Increases GTP Cyclohydrolase I mRNA and Tetrahydrobiopterin in Vascular Endothelial Cells. Arterioscler Thromb Vasc Biol. 2003;23(2):176-82.

81. Antoniades C, Bakogiannis C, Leeson P, Guzik TJ, Zhang M-H, Tousoulis D, et al. Rapid, direct effects of statin treatment on arterial redox state and nitric oxide bioavailability in human atherosclerosis via tetrahydrobiopterin-mediated endothelial nitric oxide synthase coupling. Circulation. 2011;124(3):335-45.

82. Carneado J, Alvarez de Sotomayor M, Perez-Guerrero C, Jimenez L, Herrera MD, Pamies E, et al. Simvastatin improves endothelial function in spontaneously hypertensive rats through a superoxide dismutase 
mediated antioxidant effect. J Hypertens. 2002;20(3):429-37.

83. European Stroke Organisation, Tendera M, Aboyans V, Bartelink M, Baumgartner I, Clément D, et al. ESC Guidelines on the diagnosis and treatment of peripheral artery diseases: Document covering atherosclerotic disease of extracranial carotid and vertebral, mesenteric, renal, upper and lower extremity arteries: the Task Force on the Diagnosis and Treatm. Eur Heart J. 2011;32(22):2851-906.

84. Rooke TW, Hirsch AT, Misra S, Sidawy AN, Beckman JA, Findeiss LK, et al. 2011 ACCF/AHA Focused Update of the Guideline for the Management of Patients With Peripheral Artery Disease (Updating the 2005 Guideline). Circulation. 2011;124(18).

85. Stone NJ, Robinson JG, Lichtenstein AH, Bairey Merz CN, Blum CB, Eckel RH, et al. 2013 ACC/AHA Guideline on the Treatment of Blood Cholesterol to Reduce Atherosclerotic Cardiovascular Risk in Adults. J Am Coll Cardiol. 2014;63(25 Part B).

86. Fleisher LA, Fleischmann KE, Auerbach AD, Barnason SA, Beckman JA, Bozkurt B, et al. 2014 ACC/AHA Guideline on Perioperative Cardiovascular Evaluation and Management of Patients Undergoing Noncardiac Surgery: Executive Summary. Circulation. 2014;130(24):2215-45.

87. Silva M, Matthews ML, Jarvis C, Nolan NM, Belliveau P, Malloy M, et al. Meta-analysis of drug-induced adverse events associated with intensivedose statin therapy. Clin Ther. 2007;29(2):253-60.

88. Silva MA, Swanson AC, Gandhi PJ, Tataronis GR. Statin-related adverse events: A meta-analysis. Clin Ther. 2006;28(1):26-35.

89. Hsia J, MacFadyen JG, Monyak J, Ridker PM. Cardiovascular Event Reduction and Adverse Events Among Subjects Attaining Low-Density Lipoprotein Cholesterol. J Am Coll Cardiol. 2011;57(16):1666-75.

90. Stock J. Statin-associated muscle symptoms EAS Consensus Panel paper focuses on this neglected patient group. Atherosclerosis. $2015 ; 242(1): 346-50$.

91. Gillett RC, Norrell A. Considerations for safe use of statins: liver enzyme abnormalities and muscle toxicity. Am Fam Physician. 2011;83(6):711-6.

92. Welten GMJM, Schouten O, Hoeks SE, Chonchol M, Vidakovic R, van 
Domburg RT, et al. Long-Term Prognosis of Patients With Peripheral Arterial Disease: A Comparison in Patients With Coronary Artery Disease. J Am Coll Cardiol. 2008;51(16):1588-96.

93. Heart Protection Study Collaborative Group. Randomized trial of the effects of cholesterol-lowering with simvastatin on peripheral vascular and other major vascular outcomes in 20,536 people with peripheral arterial disease and other high-risk conditions. J Vasc Surg. 2007;45(4):645-54.

94. Antoniou GA, Fisher RK, Georgiadis GS, Antoniou SA, Torella F. Statin therapy in lower limb peripheral arterial disease: Systematic review and meta-analysis. Vascul Pharmacol. 2014;63(2):79-87.

95. De Martino RR, Beck AW, Hoel AW, Hallett JW, Arya S, Upchurch GR, et al. Preoperative antiplatelet and statin treatment was not associated with reduced myocardial infarction after high-risk vascular operations in the Vascular Quality Initiative. J Vasc Surg. 2016;63(1):182-9. 


\section{TABLE LEGENDS}

\section{Table 1: Statin use in PAD and CV outcomes}

Abbreviations: RCT, randomised controlled study; CLI, chronic limb ischaemia; $\mathrm{OR}$, odds ratio; HR, hazard ratio; PAD, peripheral arterial disease; LDL, low density lipoprotein; ACE, angiotensin converting enzyme; MI, myocardial infarction; MACE, major adverse cardiac events; RCT, randomized controlled trial; $\mathrm{Rx}$, treatment; $\mathrm{CV}$, cardiovascular

\section{Table 2: Statin use in PAD and symptom-related outcomes}

Abbreviations: RCT, randomised controlled trial; PAD, peripheral arterial disease; MI, myocardial infarction

\section{FIGURE LEGEND}

Figure 1: Pathways in the atherosclerotic process that may be affected by statin use

Alongside its primary lipid-lowering action, the blocking of multiple pathways downstream of $\mathrm{HMG}-\mathrm{CoA}$ reductase pathway with statin use results in a number of pleiotropic effects that may additionally contribute to a reduction in atherosclerotic risk in PAD patients. These pathways have been shown to affect every stage of the disease process from the initial development of endothelial dysfunction to the stabilisation of vulnerable established plaques. The arrows demonstrate pathways that can be affected by statin use. 
Table 1: Statin use in PAD and CV outcomes

\begin{tabular}{|c|c|c|c|c|}
\hline Author/ Year & Study type & Study group & Statin / follow up & CV Outcome \\
\hline $\begin{array}{l}\text { HPS } 2002 \\
(6)\end{array}$ & RCT & $\begin{array}{l}20536 \text { adults } 40-80 \text { years with } \\
\text { CAD, occlusive arterial disease or } \\
\text { diabetes }\end{array}$ & $\begin{array}{l}\text { Simvastatin } 40 \mathrm{mg} / \mathrm{d} \text { vs } \\
\text { placebo } 5 \text { year follow up }\end{array}$ & $\begin{array}{l}\text { Reduced all-cause mortality in simvastatin } \\
\text { group }\end{array}$ \\
\hline $\begin{array}{l}\text { HPS } 2007 \\
(93)\end{array}$ & RCT & $\begin{array}{l}6748 \text { patients with PAD and } 13788 \\
\text { other high risk patients }\end{array}$ & $\begin{array}{l}\text { Simvastatin } 40 \mathrm{mg} / \mathrm{d} \text { vs } \\
\text { placebo for mean of } 5 \text { years }\end{array}$ & $\begin{array}{l}\text { Reduction in first major vascular event by } \\
25 \% \text { and that of peripheral vascular events } \\
\text { by } 1 / 6 \text { in simvastatin group }\end{array}$ \\
\hline $\begin{array}{l}\text { Aronow \& Ahn } \\
2002 \text { (7) }\end{array}$ & $\begin{array}{l}\text { Prospective } \\
\text { follow up study }\end{array}$ & $\begin{array}{l}264 \text { men and } 396 \text { women mean } \\
\text { age } 80+/-9 \text { years with PAD and } \\
\text { LDL }>125 \mathrm{mg} / \mathrm{dl} \text {. Among those } 318 \\
\text { were on statin and the remaining } \\
\text { on no lipid lowering treatment }\end{array}$ & $\begin{array}{l}90 \% \text { of } 318 \text { patients who } \\
\text { were treated with statins } \\
\text { were on simvastatin } 20- \\
40 \mathrm{mg} / \mathrm{d}, 9 \% \text { with pravastatin } \\
40 \mathrm{mg} / \mathrm{d} \text { and } 1 \% \text { with } \\
\text { lovastatin } 40 \mathrm{mg}\end{array}$ & $\begin{array}{l}\text { Significant reduction in incidence of } \\
\text { coronary event in those treated with statins. }\end{array}$ \\
\hline $\begin{array}{l}\text { Schillinger et al } \\
2004(70)\end{array}$ & $\begin{array}{l}\text { Prospective } \\
\text { observational } \\
\text { study }\end{array}$ & $\begin{array}{l}515 \text { patients with severe PAD } \\
\text { (median age } 70 \text { years). } 52 \% \text { were } \\
\text { on statin }\end{array}$ & $\begin{array}{l}\text { No statin type or dose } \\
\text { specified/ median follow up } \\
21 \text { months }\end{array}$ & $\begin{array}{l}\text { Statin Rx was associated with improved } \\
\text { intermediate-term survival only in PAD } \\
\text { patients with high inflammatory activity }\end{array}$ \\
\hline $\begin{array}{l}\text { Feringa et al } 2006 \\
\text { (8) }\end{array}$ & $\begin{array}{l}\text { Prospective } \\
\text { observational } \\
\text { study }\end{array}$ & 2420 PAD patients $\left(64+/ \_11\right.$ yrs $)$ & $\begin{array}{l}\text { No statin dose or type } \\
\text { specified/ median follow up } \\
8 \text { years }\end{array}$ & $\begin{array}{l}\text { Statins, beta blockers, aspirin and ACE } \\
\text { inhibitors are associated with reduction in } \\
\text { long term mortality in PAD patients }\end{array}$ \\
\hline $\begin{array}{l}\text { Feringa et al } 2007 \\
(10)\end{array}$ & $\begin{array}{l}\text { Prospective } \\
\text { observational } \\
\text { study }\end{array}$ & $\begin{array}{l}1374 \text { PAD patients }(61+/-10 \\
\text { years) }\end{array}$ & $\begin{array}{l}\text { Simvastatin, pravastatin, } \\
\text { fluvastatin, atorvastatin and } \\
\text { rosuvastatin/ mean follow up } \\
6.4+/-3.6 \text { yrs }\end{array}$ & $\begin{array}{l}\text { Higher doses of statins and lower LDL } \\
\text { cholesterol are independently associated } \\
\text { with improved outcome in PAD patients }\end{array}$ \\
\hline $\begin{array}{l}\text { Stoekenbroek et } \\
\text { al } 2015 \text { (9) }\end{array}$ & RCT & $\begin{array}{l}8888 \text { post myocardial infarction } \\
\text { patients }\end{array}$ & $\begin{array}{l}\text { Atorvastatin } 80 \mathrm{mg} / \mathrm{d} \text { vs } \\
\text { simvastatin } 20-40 \mathrm{mg} / \mathrm{d} / \\
\text { median follow up } 4.8 \text { years } \\
\end{array}$ & $\begin{array}{l}\text { High dose atorvastatin reduced the } \\
\text { incidence of PAD and incidence of coronary } \\
\text { events compared to simvastatin }\end{array}$ \\
\hline $\begin{array}{l}\text { Antoniou et al } \\
2014(94)\end{array}$ & $\begin{array}{l}\text { Systematic } \\
\text { review-meta- } \\
\text { analysis }\end{array}$ & $\begin{array}{l}12 \text { observational cohort studies } \\
\text { and } 2 \text { RCT in } 19368 \text { patients }\end{array}$ & & $\begin{array}{l}\text { Decreased all-cause mortality } \\
\text { (HR:0.77[0.68-0.86] and incidence of stroke } \\
\text { (OR:0.77[0.67-0.89] and trend towards } \\
\text { improved CV mortality in statin users }\end{array}$ \\
\hline $\begin{array}{l}\text { De Martino et al } \\
2016(95)\end{array}$ & $\begin{array}{l}\text { Retrospective } \\
\text { review from } \\
\text { Vascular }\end{array}$ & $\begin{array}{l}3039 \text { patients who underwent } \\
\text { elective suprainguinal repair } \\
8323 \text { had infrainguinal bypass }\end{array}$ & Antiplatelet and statins & $\begin{array}{l}\text { Preoperative statin and antiplatelet Rx were } \\
\text { not associated with improved rated of in- } \\
\text { hospital MI/death after major open vascular }\end{array}$ \\
\hline
\end{tabular}




\begin{tabular}{|l|l|l|l|l|}
\hline & $\begin{array}{l}\text { Quality } \\
\text { Initiative } \\
\text { database }\end{array}$ & $\begin{array}{l}\text { 3007 had open infrarenal } \\
\text { abdominal aortic aneurysm repair }\end{array}$ & operations. \\
\hline $\begin{array}{l}\text { Schanzer et al } \\
2008(19)\end{array}$ & $\begin{array}{l}\text { Observational } \\
\text { study }\end{array}$ & $\begin{array}{l}\text { 1404 patients with CLI who were } \\
\text { randomized to test the efficacy of } \\
\text { edifoligide for the prevention of } \\
\text { graft failure }\end{array}$ & $\begin{array}{l}\text { 45\% were on statins } \\
59 \% \text { were on beta-blockers } \\
\text { and 80\% were on antiplatelet } \\
\text { drugs }\end{array}$ & $\begin{array}{l}\text { Perioperative MACE and early mortality } \\
\text { were not affected by the use of any drugs. } \\
\text { survival in CLI patients 1 year after surgical } \\
\text { revascularization }\end{array}$ \\
\hline $\begin{array}{l}\text { Suckow et al } 2015 \\
(17)\end{array}$ & $\begin{array}{l}\text { Observational } \\
\text { study }\end{array}$ & $\begin{array}{l}\text { 2067 patients man age 67+/-11 } \\
\text { years with CLI who underwent } \\
\text { infranguinal bypass from 2003- } \\
\text { 2011 (Vascular Study group of } \\
\text { New England registry) }\end{array}$ & $\begin{array}{l}\text { 74\% were on statins } \\
\text { perioperatively and at 1 year } \\
\text { follow up }\end{array}$ & $\begin{array}{l}\text { Statin therapy is associated with 5 year } \\
\text { survival benefit. However, 1 year limb } \\
\text { related outcomes were not influenced by } \\
\text { statins. }\end{array}$ \\
\hline
\end{tabular}


Table 2: Statin use in PAD \& symptom-related outcomes

\begin{tabular}{|c|c|c|c|c|}
\hline Author & Study type & Patients & Medication/ Follow up & Symptom-related outcomes \\
\hline Pedersen et al 1998 (12) & RCT & $\begin{array}{l}4,444 \text { patients with prior } \\
\text { MI and serum cholesterol } \\
5.5-8 \mathrm{mmol} / \mathrm{L}\end{array}$ & $\begin{array}{l}\text { Simvastatin } 20 \text { or } 40 \mathrm{mg} / \mathrm{d} \text { vs. } \\
\text { placebo for median } 5.4 \text { years }\end{array}$ & $\begin{array}{l}\text { Statin treatment associated with } 38 \% \\
\text { reduced risk of new or worsening IC } \\
\text { and } 48 \% \text { reduced risk of new or } \\
\text { worsening carotid bruits compared to } \\
\text { placebo. }\end{array}$ \\
\hline Mohler et al 2003 (13) & RCT & $\begin{array}{l}354 \text { patients with } \\
\text { claudications }\end{array}$ & $\begin{array}{l}\text { Atorvastatin } 10 \mathrm{mg} / \mathrm{d} \text { or } \\
80 \mathrm{mg} / \mathrm{d} \text { vs. placebo for } 12 \\
\text { months }\end{array}$ & $\begin{array}{l}\text { The } 80 \mathrm{mg} \text { atorvastatin group } \\
\text { improved pain free walking distance } \\
\text { by } 63 \% \text { vs } 38 \% \text { in the placebo. There } \\
\text { was no difference between } 10 \mathrm{mg} \\
\text { atorvastatin and placebo }\end{array}$ \\
\hline Aronow et al 2003 (14) & RCT & 69 patients with PAD & $\begin{array}{l}\text { Simvastatin } 40 \mathrm{mg} / \mathrm{d} \text { vs } \\
\text { placebo }\end{array}$ & $\begin{array}{l}\text { Increase in treadmill exercise time of } \\
24 \% \text { at } 6 \text { months and } 42 \% \text { at } 12 \\
\text { months in simvastatin group } \\
\text { compared to placebo }\end{array}$ \\
\hline Mondillo et al 2003 (15) & RCT & 86 patients with $\mathrm{PAD}$ & $\begin{array}{l}\text { Simvastatin } 40 \mathrm{mg} / \mathrm{d} \text { vs } \\
\text { placebo }\end{array}$ & $\begin{array}{l}\text { Simvastatin group was associated with } \\
\text { significant increase in 90meters pain } \\
\text { free walking distance compared to } \\
\text { placebo }\end{array}$ \\
\hline McDermott et al 2003 (16) & $\begin{array}{l}\text { Prospective } \\
\text { observational } \\
\text { study }\end{array}$ & 392 PAD patients & $\begin{array}{l}\text { Statins, aspirin, beta blocker, } \\
\text { ACE inhibitors and } \\
\text { vasodilators }\end{array}$ & $\begin{array}{l}\text { Statins were associated with superior } \\
\text { leg functioning independent of } \\
\text { cholesterol levels compared to no } \\
\text { statin use }\end{array}$ \\
\hline Khumbani et al 2014 (18) & $\begin{array}{l}\text { Retrospective } \\
\text { review }\end{array}$ & $\begin{array}{l}5,861 \text { patients with } \\
\text { symptomatic PAD }\end{array}$ & $\begin{array}{l}62.2 \% \text { on statins at baseline } \\
(74.5 \% \text { in patients with } \\
\text { concomitant CAD and } 64.0 \% \\
\text { in patients with concomitant } \\
\text { CBVD) with } 4 \text { year follow-up }\end{array}$ & $\begin{array}{l}\text { Statins were associated with } 18 \% \\
\text { lower rate of adverse limb outcomes } \\
\text { (worsening symptoms, peripheral } \\
\text { revascularisations, ischaemic } \\
\text { amputations) at } 4 \text { years }\end{array}$ \\
\hline Westin et al 2014 (20) & $\begin{array}{l}\text { Retrospective } \\
\text { review }\end{array}$ & $\begin{array}{l}380 \text { CLI patients following } \\
\text { diagnostic angiography or } \\
\text { endovascular } \\
\text { intervention }\end{array}$ & $\begin{array}{l}65 \% \text { on statins } \\
\text { perioperatively with median } 1 \\
\text { year follow-up }\end{array}$ & $\begin{array}{l}\text { Statins were associated with increased } \\
\text { amputation-free survival and lower } \\
\text { rates of mortality and MACE }\end{array}$ \\
\hline
\end{tabular}




\begin{tabular}{|l|l|l|l|l|}
\hline Abbruzzese et al 2004 (22) & $\begin{array}{l}\text { Retrospective } \\
\text { review }\end{array}$ & $\begin{array}{l}\text { 172 PAD patients } \\
\text { undergoing autogenous } \\
\text { infrainguinal } \\
\text { reconstructions }\end{array}$ & $\begin{array}{l}\text { 49.7\% of patients on statins at } \\
\text { time of procedure with 2 year } \\
\text { follow-up }\end{array}$ & $\begin{array}{l}\text { Statin therapy associated with } \\
\text { improved graft patency. Risk of graft } \\
\text { failure 3.2x higher in control group. }\end{array}$ \\
\hline Aiello et al 2012 (23) & $\begin{array}{l}\text { Retrospective } \\
\text { review }\end{array}$ & $\begin{array}{l}\text { 646 patients with PAD } \\
\text { undergoing endovascular } \\
\text { intervention for CLI }\end{array}$ & $\begin{array}{l}\text { 49.4\% of patients on statins at } \\
\text { time of procedure with 2 year } \\
\text { follow-up }\end{array}$ & $\begin{array}{l}\text { Statins associated with improved } \\
\text { primary and secondary patency, limb } \\
\text { salvage rates, and overall survival }\end{array}$ \\
\hline Siracuse et al 2012 (24) & $\begin{array}{l}\text { Retrospective } \\
\text { review }\end{array}$ & $\begin{array}{l}\text { 218 patients undergoing } \\
\text { their first intervention for } \\
\text { claudication due to } \\
\text { superficial femoral artery } \\
\text { disease }\end{array}$ & $\begin{array}{l}\text { Statin use at baseline in 62\% } \\
\text { of patients undergoing lower } \\
\text { extremity bypass and 69\% of } \\
\text { patients undergoing } \\
\text { percutaneous transluminal } \\
\text { angioplasty } \pm \text { stent }\end{array}$ & $\begin{array}{l}\text { Statin therapy improved overall } \\
\text { freedom from stenosis and symptom } \\
\text { recurrence. No differences observed in } \\
3 \text { year mortality. }\end{array}$ \\
\hline Henke et al 2004 (25) & $\begin{array}{l}\text { Retrospective } \\
\text { review }\end{array}$ & $\begin{array}{l}\text { 293 patients undergoing } \\
\text { infrainguinal bypass, } \\
\text { predominantly for limb } \\
\text { salvage }\end{array}$ & $\begin{array}{l}\text { Statins, ACE inhibitors, and } \\
\text { antiplatelet agents or warfarin }\end{array}$ & $\begin{array}{l}\text { Statin therapy associated with } \\
\text { improved graft patency and limb } \\
\text { salvage }\end{array}$ \\
\hline
\end{tabular}


Figure 1: Pathways in the atherosclerotic process that may be affected by statin use

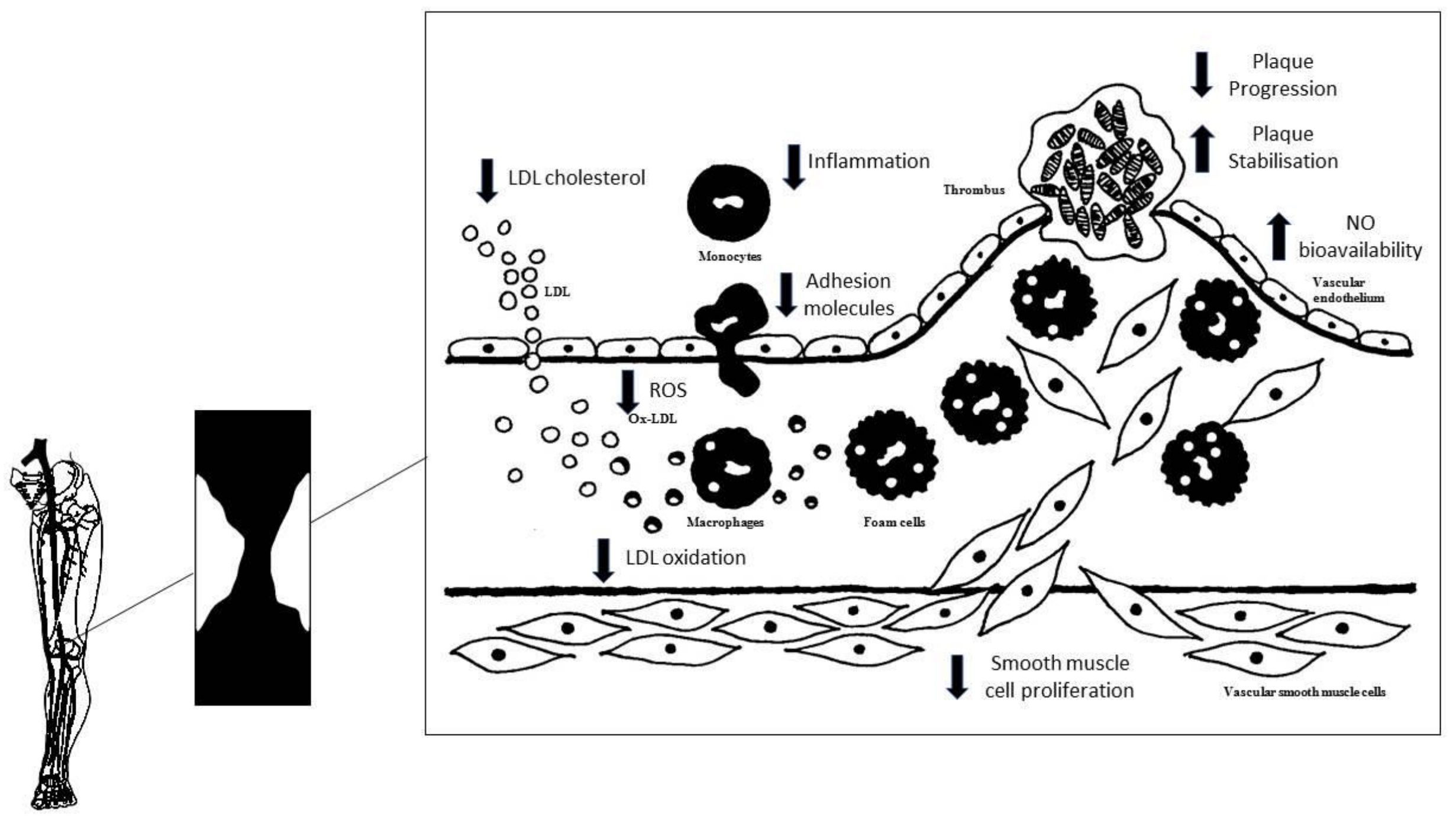

